\title{
A Fundamental Study of the Silla Shield through the Analysis of the Shape, Dating, and Species Identification of Wooden Shields Excavated from the Ruins of Wolseong Moat in Gyeongju $u^{1}$
}

\author{
Tae-Gwang NAM(D) ${ }^{2, \dagger} \cdot$ Hun-Suk KIM ${ }^{2}$
}

\begin{abstract}
Various types of wooden relics are being unearthed following the full-scale excavation in Wolseong palace site, Gyeongju in Korea. In particular, a large number of relics were found in the moat surrounding the Wolseong Fortress. This study attempted to secure basic data on the shields of the Silla era through species identification, radiocarbon dating, and shape analysis of the two wooden shields excavated from the Wolseong moat. As a result of the radiocarbon dating, it was confirmed that the shields were made of wood procured in the period between the mid-4th century and the early 5th century. The species identification confirmed that the body of the relic was made with Pinus soft pine group and the handle with Zelkova serrata. It was also confirmed that the excavated wooden shield was made by first marking a thin line on a flat grain board, then marking double concentric circles and perforating small holes. The distance between the division lines is constant at about $6 \mathrm{~cm}$, and spaces between them are colored in red and black. The shape analysis estimated that two artifacts were more than $50 \mathrm{~cm}$ and $36 \mathrm{~cm}$ in width, respectively.
\end{abstract}

Keywords: wooden shield, radiocarbon dating, wood identification, wolseong, moat, silla

\section{INTRODUCTION}

The Wolseong moat is a defense facility built on the outskirts of Wolseong, the royal castle of Silla. To protect the interior, Namcheon Stream was used as a natural moat, and in the north, east, and west, ditches were dug outside the castle and filled with water to serve as a defense facility. Defense facilities on the Korean Peninsula, such as moats, were built in Goguryeo Guknaeseong, Baekje Pungnaptoseong Fortress, and Silla Wolseong, along with the ditches of prehistoric settlements and the appearance of castle walls in ancient cities. Besides, many artificial or natural moats of various forms in ancient and middle-age cities have also been found in China and Japan (Park and Choi, 2017).

Various types of wooden relics have been unearthed from the walls and moat of Wolseong, Gyeongju with the full-scale excavation. In particular, a large number of relics are being found from the moat surrounding

\footnotetext{
${ }^{1}$ Date Received December 23, 2020, Date Accepted February 26, 2021

${ }^{2}$ Curatorial Affairs Division, Gyeongju National Research Institute of Cultural Heritage, Gyeongju-si 38170, Republic of Korea

$\dagger$ Corresponding author: Tae-Gwang NAM (e-mail: tour9317@korea.kr, ORCID: 0000-0002-7155-9595)
} 
A Fundamental Study of the Silla Shield through the Analysis of the Shape, Dating, and Species Identification of Wooden Shields Excavated from the Ruins of Wolseong Moat in Gyeongju

Wolseong Fortress. It is due to the unique environment where moats are situated. A moat, being filled with water, is a wetland located on a lower ground level than its surrounding, so the place remains moist with the water always accumulating (Jung et al., 2010; Peña-Monné et al., 2014; Zhuang et al., 2017). Wood is composed of organic matter, and as time goes by, its tissues decompose and get destroyed by insects, bacteria, chemical changes, etc., losing its shape and eventually disappearing. However, in low wetlands, mudflat or mud layer forms an enclosed space, creating a hypoxic or oxygen-free environment that slows the decomposition process of organic matter. The decomposition rate is slower in such an environment, and water fills the space where the main component of wood decomposes, allowing the wooden relics to remain in the form they were in at the time of disposal (Pearson, 1988; Yi, 1997; Rodgers, 2004; Seo, 2008).

The wooden relics excavated as close to their original form make it possible to restore through archaeological and scientific research the natural environment of those days. They also provide important information for restoring daily life through daily items, tools, and building materials used by people at that time.
Currently, in Korea, various studies such as species identification, dating, manufacturing techniques, and lacquer analysis are being conducted on the components of wooden relics and old buildings excavated from many remains (Lee and Kim, 2015; Nam et al., 2015; 2017; 2018; Hwang et al., 2018; Park et al., 2018; Lee and Kim, 2018; Eom and Park, 2018; Lee et al., 2018; 2021; lee and Han, 2018; Cho et al., 2019; Hwang et al., 2020).

In the Wolseong moat, 785 artifacts made of wood were excavated, such as living tools (comb, ladle, container, lacquerware, etc.), construction materials (plates, fittings, etc.), and wooden products of unknown purpose. The most interesting artifacts among them are two wooden shields (Fig.1). This study attempted to secure basic data on the Silla era shields through species identification, natural scientific analysis such as radiocarbon dating, and shape analysis of the two wooden shields.

\section{MATERIALS and METHODS}

\subsection{Research area}

Wolseong, Gyeongju, is located in 387-1, Inwang-

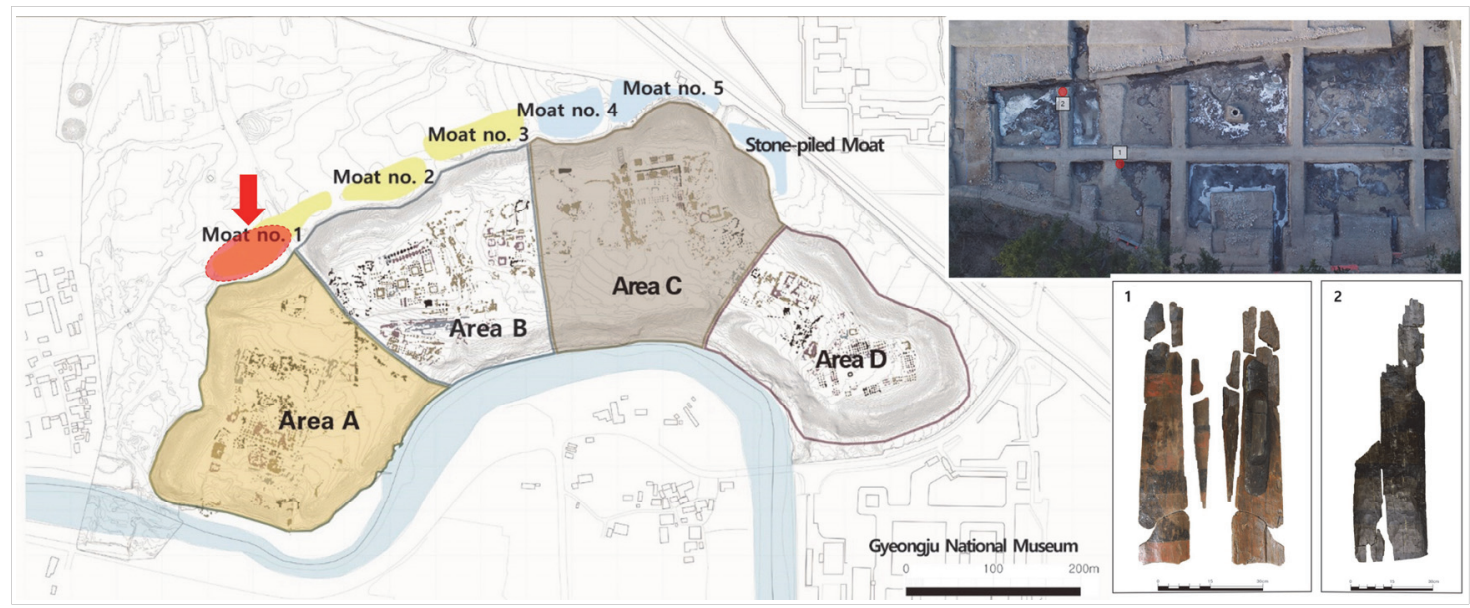

Fig. 1. Location and wooden shields excavated from Wolseong moat site. (Arrow: Research area, 1: wooden shield with handle, 2: wooden shield without handle 
dong, Gyeongju-si ( $\left.35^{\circ} 49^{\prime} 51^{\prime \prime} \mathrm{N}, 129^{\circ} 13^{\prime} 34^{\prime \prime} \mathrm{E}\right)$, and has a total area of about $193,845 \mathrm{~m}^{2}$. The area stretches $890 \mathrm{~m}$ east to west and $260 \mathrm{~m}$ north to south, and the outer circumference is $2,340 \mathrm{~m}$ forming a long half-moon shape. The Hyeongsan River flows at its west, Bukcheon at its north, and Namcheon at its south, forming an independent hill. The top of Wolseong is a wide flat surface, and the walls remaining at the edges are $2 \mathrm{~m}$ to $7 \mathrm{~m}$ higher than the flat surface. Wolseong Hills has the locational advantage to view the access paths from the outside as a whole. Presumably, it has the view of the summit of all mountains surrounding the Gyeongju Basin from here (Gyeongju National Research Institute of Cultural Heritage (GNRICH), 2010).

\subsection{Material}

Two wooden shields were unearthed in 2016 and 2018 in Moat no. 1 during excavation in the Wolseong moat site. They were excavated from the lowest layer of the stable layer, and there were two types, one with a handle and the other without it. The excavated wooden shield has a mark of a double concentric circle, and there remains the trace of a stripe carved with a sharp tool, painted in red and black, and there are small holes spaced in the regular distance. This study conducted shape analysis, species identification, and dating to restore the original shape of the unearthed wooden shield.

\subsection{Method}

\subsubsection{Species Identification}

We cut out a minimum amount of section with a razor (Dorco Co., Ltd.) from an area not visible on the surface to keep the shape of the artifact intact. The cut-out samples with three sections (cross section, radial section, tangential section) were analyzed by making a temporary preparat sealed with a temporary seal- ing agent (50\% glycerin aqueous solution). An optical microscope (Nikon ECLIPSE E200) was used to observe the constituent cells and take pictures of the features on the preparat.

The species identification was carried out by referring to Wood Structure and Identification (Park et al., 1987), Properties and Uses of Korean Wood (Lee, 1997), Organizational Structure of Korean Wood (Lee, 1994), and Wood Anatomy (Kwon et al., 2020), IAWA List of Microscopic Features for Softwood Identification (Richter et al., 2004), IAWA List of Microscopic Features for Hardwood Identification (Wheeler et al., 1989).

\subsubsection{Dating}

A very small amount (about 100mg) of samples were collected from a less visible area of the artifact, not to affect its shape. The collected sample was sent to multiple organizations (Paleo Labo in Japan, BETA in the U.S.) for examination. The sample was made into wood powder, treated with AAA (Acid-Alkaline-Acid), and measured with an accelerator mass spectrometer. The measured ${ }^{14} \mathrm{C}$ age was calculated using the Oxcal program by applying IntCal20 (Reimer et al., 2020), the most recent calibration curve (Bronk, 1995).

\section{RESULTS and DISCUSSION}

\subsection{Shape Analysis}

Two wooden shields were excavated in the Wolseong moat in Gyeongju, one with a handle and one without. The main morphological feature of the two artifacts is that their body is a flat grain board, processed into a round shape with a thickness of 1.0 to $2.0 \mathrm{~cm}$. The shield was made by first drawing a thin outline on the surface of the plate with a sharp tool, a double concentric circle was then marked, and then it was colored. In addition, small holes were perforated at 
A Fundamental Study of the Silla Shield through the Analysis of the Shape, Dating, and Species Identification of Wooden Shields Excavated from the Ruins of Wolseong Moat in Gyeongju

regular intervals, which seem to be for weaving in materials such as thread to enhance its strength. The presence and attachment method of the handle that had been unknown so far were also identified.

\subsubsection{Wooden Shield with a Handle (Fig. 1-1)}

The remaining length of the relic is $73 \mathrm{~cm}$, the width is $14.4 \mathrm{~cm}$, and it is about $1.0 \mathrm{~cm}$ thick with 3 treerings. The artifact was recovered partially, separated into 10 pieces. Three double concentric circles and seven horizontal stripes were identified, colored red and black. Two double concentric circles are adjacent, and the other one is separated. On its back, a handle with an inner diameter of about $9.6 \mathrm{~cm}$ is fixed with three pegs at the top and bottom.

A total of 18 points were measured; 3 points at each of 6 sections between the seven clear horizontal lines. It measured a minimum of $5.8 \mathrm{~cm}$, a maximum of $6.5 \mathrm{~cm}$, averaging out at $6.1 \mathrm{~cm}$. The measurements on 5 points between the concentric circles showed a minimum of $6.0 \mathrm{~cm}$, a maximum of $6.3 \mathrm{~cm}$, averaging out at $6.1 \mathrm{~cm}$. The outlines of the artifact were drawn in intervals of about $6 \mathrm{~cm}$. Therefore, as the diameter of the double concentric circles was calculated as $24 \mathrm{~cm}$ and the distance between the double concentric circles was measured as $2 \mathrm{~cm}$, the width of this artifact was estimated to be at least $50 \mathrm{~cm}$.

\subsubsection{Wooden Shield without a Handle (Fig. 1-2)}

The length of the remaining relic is $95.5 \mathrm{~cm}$, the width is $26.3 \mathrm{~cm}$, and its thickness is $1.2 \mathrm{~cm}$ with 6 tree rings. The relic was recovered partially, separated into nine pieces. One double concentric circle and 16 horizontal stripe lines were identified, and they are colored only in black. The trace of an attached handle wasn't confirmed.

A total of 45 points were measured; 3 points for each of the 15 sections between the 16 clear horizontal lines, and the result shows a minimum of $5.0 \mathrm{~cm}$, a maximum of $6.4 \mathrm{~cm}$, and an average of $5.7 \mathrm{~cm}$. The measurements of 5 points between the concentric circle show a minimum of $5.3 \mathrm{~cm}$, a maximum of $6.3 \mathrm{~cm}$, averaging out at $5.9 \mathrm{~cm}$. The outlines of this artifact

Table 1. Measurement results of wooden shields with handles $(\mathrm{cm})$

\begin{tabular}{c|c|c|c|c|}
\hline \multirow{2}{*}{$\begin{array}{c}\text { Gap } \\
\text { /Spot }\end{array}$} & \multicolumn{3}{|c|}{ Horizontal Line } & $\begin{array}{c}\text { Double } \\
\text { Concentric } \\
\text { Circle }\end{array}$ \\
\cline { 2 - 5 } & 1 & 2 & 3 & 6.0 \\
\hline 1 & 6.0 & 6.1 & 5.9 & 6.1 \\
\hline 2 & 6.5 & 6.2 & 6.4 & 6.3 \\
\hline 3 & 6.3 & 6.2 & 6.4 & 6.3 \\
\hline 4 & 5.8 & 5.8 & 5.9 & 6.0 \\
\hline 5 & 6.4 & 6.5 & 6.2 & 6.0 \\
\hline Average & 6.2 & 6.1 \\
\hline \multicolumn{3}{c}{ Min } & 5.8 & 6.0 \\
\hline
\end{tabular}

Table 2. Measurement results of wooden shields without handles $(\mathrm{cm})$

\begin{tabular}{|c|c|c|c|c|c|}
\hline \multirow{2}{*}{$\begin{array}{l}\text { Gap } \\
\text { /Spot }\end{array}$} & \multicolumn{3}{|c|}{ Horizontal Line } & \multirow{2}{*}{$\begin{array}{c}\text { Double } \\
\text { Concentric } \\
\text { Circle }\end{array}$} & \\
\hline & 1 & 2 & 3 & & \\
\hline 1 & 5.3 & 5.2 & 5.3 & 6.0 & \\
\hline 2 & 5.8 & 5.8 & 5.5 & 5.7 & \\
\hline 3 & 5.7 & 5.6 & 5.5 & 5.7 & \\
\hline 4 & 6.3 & 6.0 & 5.9 & 6.3 & \\
\hline 5 & 6.1 & 6.2 & 6.2 & 5.6 & \\
\hline 6 & 5.9 & 5.5 & 5.2 & & \\
\hline 7 & 5.7 & 5.5 & 5.8 & & \\
\hline 8 & 6.2 & 6.4 & 6.3 & & \\
\hline 9 & 5.8 & 5.5 & 5.3 & & \\
\hline 10 & 5.5 & 5.5 & 5.1 & & \\
\hline 11 & 5.2 & 5.5 & 5.6 & & \\
\hline 12 & 5.8 & 5.5 & 5.0 & & \\
\hline 13 & 5.9 & 5.8 & 5.6 & & \\
\hline 14 & 6.0 & 5.9 & 6.1 & & \\
\hline \multicolumn{2}{|c|}{ Average } & \multicolumn{2}{|c|}{$\begin{array}{l}1 \\
.7\end{array}$} & 5.9 & \multirow[t]{3}{*}{$\forall \forall e^{x-1}$} \\
\hline \multicolumn{2}{|c|}{ Min } & \multicolumn{2}{|c|}{5.0} & 5.6 & \\
\hline \multicolumn{2}{|c|}{ Max } & \multicolumn{2}{|c|}{6.4} & 6.3 & \\
\hline
\end{tabular}


were drawn at intervals of about $6 \mathrm{~cm}$. Therefore, the diameter of the double concentric circle was calculated as $24 \mathrm{~cm}$, and as the distance between the double concentric circle and the fully remaining side was measured as $6 \mathrm{~cm}$, the width of this artifact was estimated to be at least $36 \mathrm{~cm}$.

\subsubsection{Excavation Examples}

Among the relics unearthed in Korea, the first assumed or confirmed example of a shield is Nopo-dong No. 31, which is dated to the second half of the $3 \mathrm{rd}$ century (Lee, 2015). It was identified in tombs of the Three Kingdoms period, such as in Bokcheon-dong and Daeseong-dong tombs. The three wooden artifacts excavated from the wetland remains in Imdang-dong, Gyeongsan are believed to be shields. On the wooden shields excavated in Imdang-dong, a double concentric circle and a stripe-shaped sketch were drawn with a sharp tool and painted in red and black. There are small holes at regular intervals. Most of them were lost and only parts of them were excavated, making it difficult to understand the overall appearance (Fig. 2).

Based on the Mukseo written on the mural, the Anak Tomb No. 3 Parade Painting (NRICH and Seoul Baekje Museum (SBM), 2018) is estimated to be created in the year 357 (27th year of King Gogukwon of Goguryeo), and it illustrates two types of shields and two methods of carrying. The shield types identified through the mural are one with a shape of two red ovals combined and another in the shape of an elongated rhombus. From the structure inside the shield, we can infer that a handle may have existed depending on the method to carry it. From the mural, we can infer two methods of carrying; mounting it on the side of the body (Fig. 3 upper left of the enlarged photo) and holding it horizontally at the side (Fig. 3

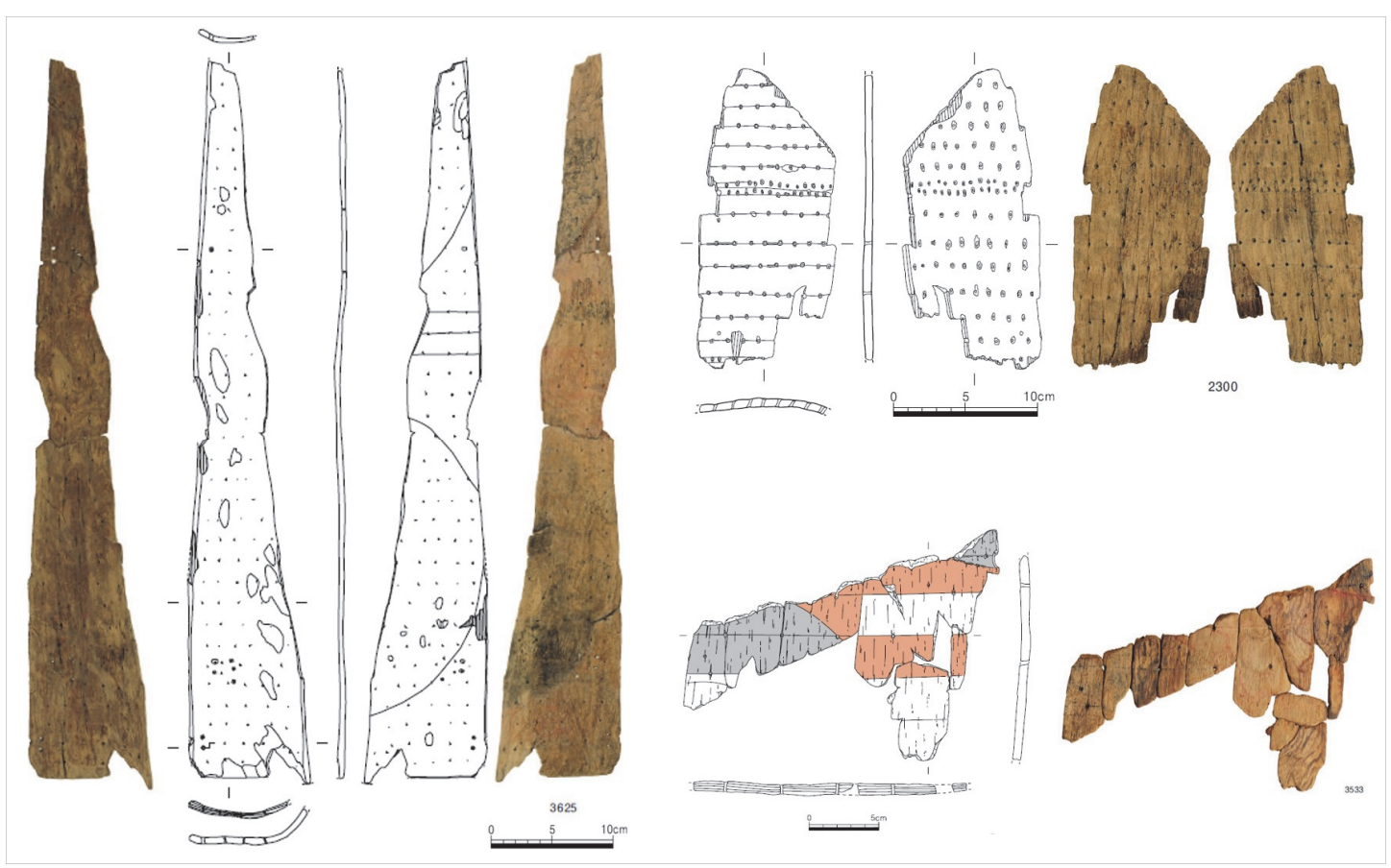

Fig. 2. Wooden shields excavated from Imdang-dong, Gyeongsan (Yeongnam Institute of Cultural Properties (YICP), 2014). 
A Fundamental Study of the Silla Shield through the Analysis of the Shape, Dating, and Species Identification of Wooden Shields Excavated from the Ruins of Wolseong Moat in Gyeongju

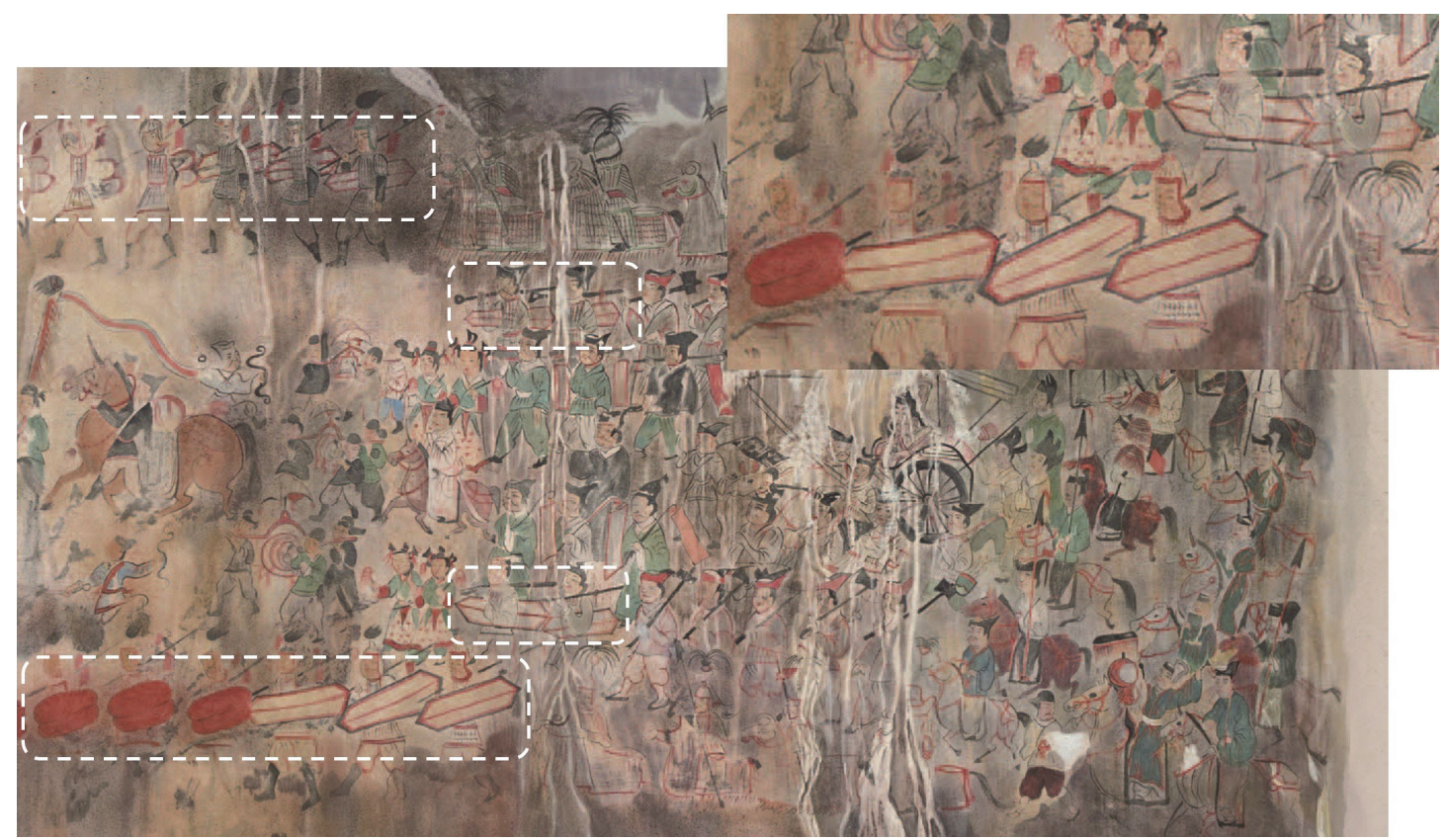

Fig. 3. Procession paintings of Goguryeo Anak No.3 tomb (modified from NRICH and SBM, 2018).

center and enlarged photo). This movement confirms that there must be a handle, enabling them to carry the shield as shown in the figure.

In the Imdang-dong wetland, the parts belonging to the shield were excavated, but there was no trace of a handle attached to a shield. Besides, it is difficult to estimate the overall shape of the shield from the state of the remaining relics. We can only confirm from the Goguryeo Mural Tombs that the two types of shields, i.e. one with a handle and one without, were used during the Three Kingdoms period.

\subsection{Species Identification Results}

\subsubsection{Pinaceae Pinus soft pine group}

The body of the excavated wooden shield was made of coniferous wood, and the transition between the earlywood and latewood was relatively gentle. The axial intercellular canal with thin-walled epithelial cells could be observed in the cross section (Fig. 4 A). In the radial section, the ray consisted of ray tracheid and ray parenchyma cells, and the cross-field pitting were window-like. There was one row of bordered pit of the tracheid wall (Fig. 4 B). The ray in the tangential section is composed of uniseriate ray and fusiform ray with radial intercellular canal (Fig. 4 C). It was identified as a soft pine group, which differs from the hard pine group where the dentate thickening could be seen due to the smooth ray tracheid.

\subsubsection{Ulmaceae Zelkova serrata (Thunb.) Makino.}

The handle of the excavated wooden shield is a ring-porous wood with one or two rows of large vessels on the cross section. The large vessels are usually circular and independent, and the smaller vessels form polygonal, short tangential pore groups (Fig. 4 D). In the radial section, a simple perforation plate was observed, and parenchyma strands in axial parenchyma cell were observed around the pores. It is a heteroge- 


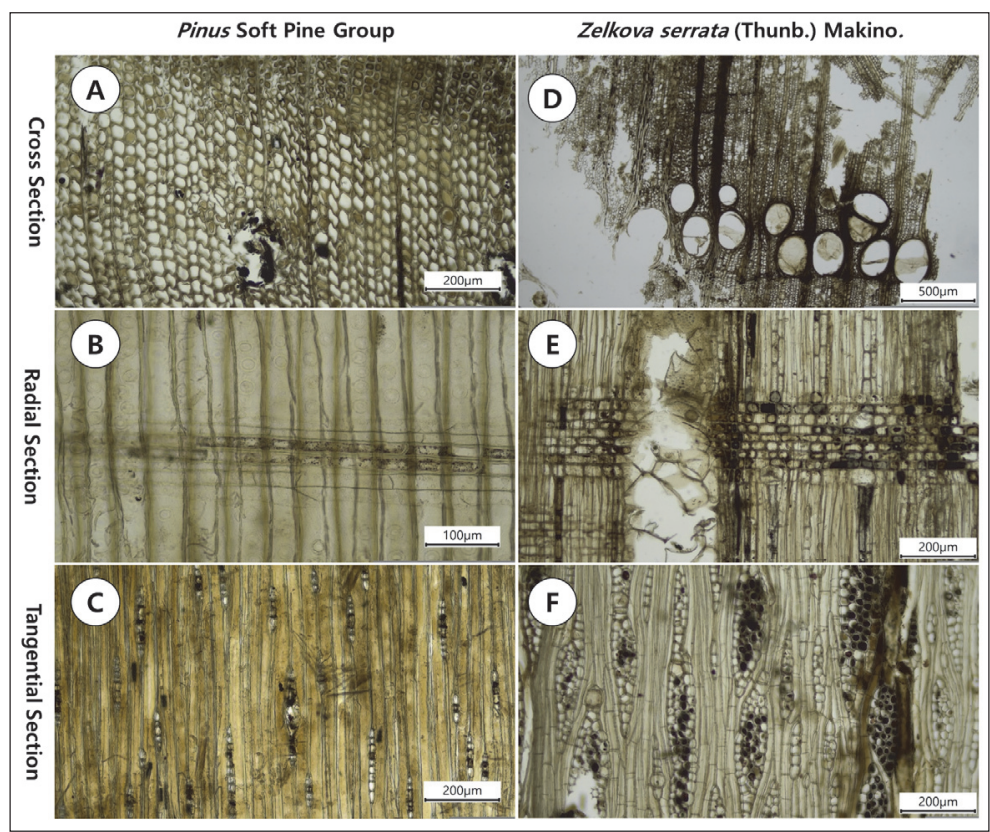

Fig. 4. Light micrographs of wooden shields excavated from Wolseong moat site.

neous ray, consisting of procumbent ray cells and square ray cells, and rhomboidal crystals are commonly observed in the square ray cells (Fig. 4 E). In the tangential section, helical thickening can be observed in the small vessels. Most of the rays have $5 \sim 6$ rows, but $1 \sim 3$ rows are also mixed. The rays are heterogeneous type III, with both ends longer than other rays (Fig. 4 F). In Korea, only one type is growing in the genus of zelkova, so it was identified as Zelkova serrata.

\subsubsection{Remarks on the Results of Species Identification of the Excavated Wooden Shields}

The Pinus soft pine group (Korean Pine) was used to make the body of the wooden shield. The Silla Civil Document contains contents related to the Korean Pine tree. It recorded the number of mulberries, walnuts, and pine trees that had been previously growing, separately from the number of newly planted trees. It is the first record about artificial afforestation, and the pine tree was one of the tree species managed by the state. The Korean Pine trees are called soft pine or white pine, as they are soft and light in color with little resin contained. Compared to Pinus densiflora, belonging to Pinus hard pine group, the Korean Pine was softer and thus easy to process. The Zelkova serrata (Zelkova) used in making the handles have a lot of extracts, making it less likely to rot or be damaged by insects. It is less prone to cracks or twists when drying, is hard, and also resistant to friction or shock (Park and Lee, 2007).

The Korean Pine and Zelkova were used for Korean architectures and the wooden artifacts excavated from Wolseong and Anapji sites in Gyeongju of the Three Kingdoms period (Lee, 2007; Nam, 2018), the remains of Hwangnyongsa Square (Foundation of Silla Cultural Heritage Research Institute, 2018), and the wetland site in Imdang-dong, Gyeongsan (YICP, 2014; Park and Lee, 2007). 
A Fundamental Study of the Silla Shield through the Analysis of the Shape, Dating, and Species Identification of Wooden Shields Excavated from the Ruins of Wolseong Moat in Gyeongju

\subsection{Results of Dating}

The radiocarbon dating results of the two wooden shields of Wolseong are as shown in Table 3 and Fig. 5. For more reliable results, the wooden shield with a handle was cross-validated through examinations by different organizations.

In the case of the wooden shield with a handle, the calibrated age (95.4\% confidence interval) calculated from the values of the two institutions (BETA, Paleo Labo) were $\mathrm{AD} 382$ to 541 and $\mathrm{AD} 262$ to 274, or $\mathrm{AD} 348$ to 428 , respectively. We found it reliable, as the ages calculated by the two organizations fall in a similar range of period. We can also interpret that the shield was produced using wood cut down between $\mathrm{AD} 382$ and 428. For the wooden shield without a handle, the calibrated age was AD 264 to 273 years or $\mathrm{AD} 348$ to 420 years at the $95.4 \%$ confidence interval.

The calibrated age of the two wooden shields overlaps between the mid- 4th and early 5 th centuries. In addition, since they have been excavated from the same level of the remains, they are considered to have been manufactured, used, and discarded at the same period. Also, this period coincides with the dating of wooden structures on the shore of the Wolseong moat and of the animal and plant fluids from the bottom of the moat (Ahn, 2018), which is between the late 4th century and the early 5th century. Therefore, we can see that these artifacts and the wooden structure existed at the same time.

\section{CONCLUSION}

In this study, analysis of shape, species identi-

Table 3. The results of radiocarbon dating of wooden shields excavated from Wolseong site

\begin{tabular}{c|c|c|c|c|c}
\hline \multirow{2}{*}{ Sample } & $\begin{array}{c}\text { Analysis } \\
\text { Institute }\end{array}$ & ${ }^{14} \mathrm{C}$ date $(\mathrm{BP})$ & $\Delta^{13} \mathrm{C}(\%)$ & $\begin{array}{c}\text { Calibrated dates } \\
(\mathrm{AD}, 95.4 \% \text { C.I.**) }\end{array}$ & Remark \\
\hline \hline \multirow{2}{*}{1} & BETA & $1630 \pm 30$ & -23.1 & $382 \sim 541(95.4 \%)$ & \multirow{2}{*}{ Cross check } \\
\cline { 2 - 5 } & Paleo Labo & $1665 \pm 19$ & -26.18 & $\begin{array}{l}262 \sim 274(4.1 \%) \\
348 \sim 428(91.3 \%)\end{array}$ & $\begin{array}{l}264 \sim 273(3.2 \%) \\
354 \sim 420(92.3 \%)\end{array}$ \\
\hline
\end{tabular}

1: Wooden shield with handle

2: Wooden shield without handle

* BP: before present, the year from A.D. 1950

** C.I.: confidence interval

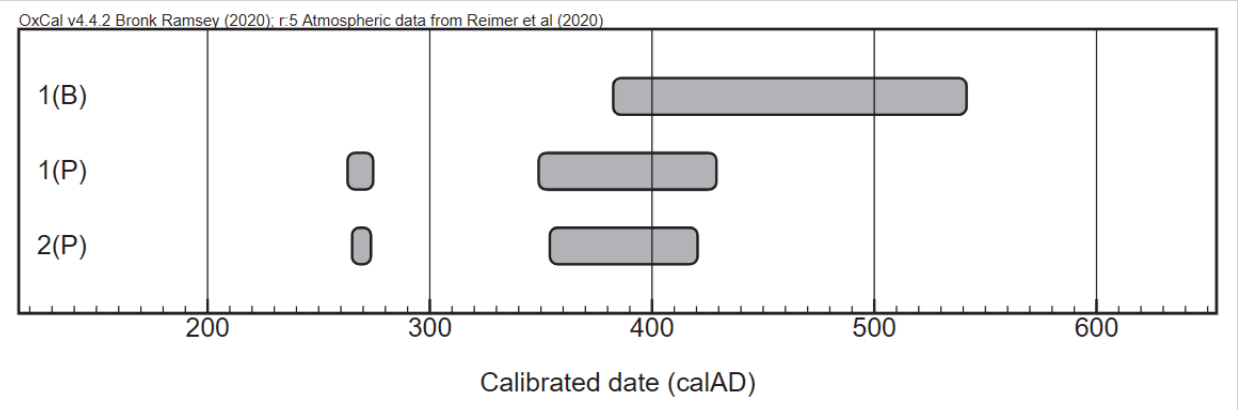

Fig. 5. The results of radiocarbon dating of wooden shields excavated from Wolseong site (B: BETA, P: Paleo Labo). 
fication, and dating were performed on the two wooden shields excavated during the excavation of the Wolseong moat site in Gyeongju. We have arrived at the following conclusions.

1) The production sequence of the wooden shield was confirmed; marking the outline on a processed plate with a thin line, drawing double concentric circles, and then drilling small holes. The distance between division lines was constant at around $6 \mathrm{~cm}$ and the space between them was colored in red and black. Each artifact was estimated to be at least $50 \mathrm{~cm}$ and $36 \mathrm{~cm}$ in width.

2) As a result of the species identification, the body of the relic was identified as Pinaceae Pinus soft pine group that is easy to process due to its soft material, and the handle was identified as Ulmaceae Zelkova serrata (Thunb.) Makino, which is hard and has less distortion.

3) The radiocarbon dating results confirmed that the excavated wooden shield was manufactured using wood procured from the middle of the 4th century to the beginning of the 5th century.

4) We could confirm the shape of the shield only from the wooden shields of the Three Kingdoms era excavated on the two sites of Imdang-dong and Wolseong. The wooden shields from the Wolseong ruins in Gyeongju show double concentric circles painted in red and black. Such composition and coloring are also found in the wooden shields excavated from the Imdang-dong ruins. Whether such composition and coloring are for decoration or ceremonial purposes remains to be verified through further case studies.

5) We could only assume the shape of the shield of the Three Kingdoms Period, as only traces of paint and a few pieces were available. However, excavations from Wolseong Ruins in Gyeongju made it possible to restore the shape of the shield. In particular, we found that two shapes assumed from the method of carrying coincide with what is depicted in the mural. The shields of the Wolseong Ruins in Gyeongju is a significant relic showing the armament system and advanced wood processing techniques of the Silla period, such as thin plate processing.

We have so far analyzed the wood species, date, and shape of the excavated wooden artifacts. However, we need to collect further data to completely restore the Silla period shield through morphological analysis on tools, processing methods, and pigments.

\section{ACKNOWLEDGMENT}

This study was conducted as part of the research project of Gyeongju National Research Institute of Cultural Heritage, "A Comprehensive Academic Research Project in Wolseong, Gyeongju (NRICH-2105-B04F-1)."

\section{REFERENCES}

Ann, S.H. 2019. A study on the ancient landscape reconstruction using the plant remains from the moat of Wolseong Place site, Gyeongju. Hanguk Sanggosa Hakbo. Journal of Korean Ancient Historical Society 105: 199-228.

Bronk Ramsey, C. 1995. Radiocarbon calibration and analysis of stratigraphy: The OxCal program. Radiocarbon 37(2): 425-430.

Cho, S.M., Son, B.H., Jeong, A.R., Kwon, J.H. 2019. A Study on Preferred Wood Species Depending on the Use Of Wooden Objects Excavated from Haman Seongsansansung Mountain Fortress. Journal of Conservation Science 35(6): 670-680.

Eom, Y.J., Park, B.D. 2018, Wood Species Identification of Documentary Woodblocks of Songok Clan of the Milseong Park, Gyeongju, Korea. Journal of the Korean Wood Science and Technology 46(3): 270-277. 
A Fundamental Study of the Silla Shield through the Analysis of the Shape, Dating, and Species Identification of Wooden Shields Excavated from the Ruins of Wolseong Moat in Gyeongju

Foundation of Silla Cultural Heritage Research Institute. 2018. The Silla Urban Site South of Hwangnyongsa in Gyeongju. Research Report of Antoquities Vol. 94. Gyeongju, Korea.

Gyeongju National Research Institute of Cultural Heritage. 2010. Basic Research Report of Wolseong, Gyeongju I. Research Report Vol. 59. Gyeongju, Korea.

Hwang, I.S., Park, J.H., Kim, S.C. 2018. A study on the optical characteristics according to the lacquer drying conditions for the conservation of lacquerwares. Journal of the Korean Wood Science and Technology 46(56): 610-621.

Hwang, S.W., Tazuru, S., Sugiyama, J. 2020. Wood Identification of Historical Architecture in Korea by Synchrotron X-ray Microtomography-Based Three-Dimensional Microstructural Imaging. Journal of the Korean Wood Science and Technology 48(3): 283-29

Jung, Y.J., Park, J.S., Sim, W.K. 2010. Consideration on the Moat of Wolseong Fortress at Gyuongju. Journal of the Korean Institute of Traditional Landscape Architecture 28(2): 37-44.

Kwon, O.G., Kim, N.H., Kim, J.S., Seo, J.W., Chung, Y.J. 2020. Wood Anatomy. The Wood Society of Korea, Seoul, Korea.

Lee, B.H. 2007. Species of the Archaeological Woods Excavated in Gyeongju, the Capital of Silla Dynasty. Master thesis, Chungbuk National University, Korea.

Lee, K.H., Han, G.S. 2018, Interpretation of Wood Processing Method by Tool Trace Analysis for Wooden Artifacts Excavated from Imdang-dong Site, Gyeongsan, Korea. Journal of the Korean Wood Science and Technology 46(3): 260-269.

Lee, K.H., Kim, D.Y. 2015, Preservation and Identification for Wooden Ship Timber of Bonghwang-Dong, Gimhae, Korea. Journal of Conservation Science 31(4): 341-350.

Lee, K.H., Kim, S.C. 2018. Wiggle Matched Radiocarbon
Dates of Wooden Warehouses Excavated at the Bongseon-ri Site in Seocheon, Korea. Journal of Conservation Science 34(1): 31-37.

Lee, K.H., Seo, J.W., Han, G.S. 2018. Dating Wooden Artifacts Excavated at Imdang-dong Site, Gyeongsan, Korea and Interpreting the Paleoenvironment according to the Wood Identification. Journal of the Korean Wood Science and Technology 46(3): 241-252.

Lee, K.H., Lee, U.C., Kang, P.W., Kim, S.C. 2021, Analysis and Tree-Ring Dating of Wooden Coffins Excavated from Incheon Sipjeong-Dong Site. Journal of the Korean Wood Science and Technology 49(1): 67-81.

Lee, P.W. 1994. The Structure of Wood in Korea. Jungminsa, Seoul, Korea.

Lee, P.W. 1997. Wood Properties and Uses of the Tree Species Grown in Korea I \& II. Seoul University Press, Seoul, Korea.

Lee, S.H. 2015. The Changing Nature of Three Kingdoms Period Shields and Arms of the Korean Peninsula. Hanguk Kogo-Hakbo. Journal of the Korean Archaeological Society 97: 170-207.

Nam, T.G. 2018. A Study on Wooden Artifacts Excavated from Wolseong, Gyeongju. In: Gyeongju National Research Ins. of Cultural Heritage. The Research of Paleoenvironment Reconstruction at Wolseong, pp. 205-212.

Nam, T.G., Hong, K.H., Lee, J.H. 2017. Radiocarbon Dating of a Wooden Board from Mado Shipwreck No. 4 Using Wiggle Matching. Journal of Conservation Science 33(4): 275-281.

Nam, T.G., Kim, T.J., Moon, H.S. 2015. Radiocarbon Dating of a Wooden Board from Yeongheung-do Shipwreck Using Wiggle Matching of Decennial Tree-Ring Samples. Journal of the Korean Conservation Science 31(3): 279-285.

Nam, T.G., Yoon, Y.H., Kim, E.H. 2018. Species Identification and Radiocarbon Dating for the Wooden Board from Daebudo Shipwreck No.2 
Using Wiggle Matching. Journal of Conservation Science 34(5): 359-368.

National Research Institute of Cultural Heritage, Seoul Baekje Museum. 2018. The Replicas of Goguryeo Tomb Murals in North Korea. Daejeon, Korea. Park, J.H., Oh, J.E., Hwang, I.S., Jang, H.U., Choi, J.W., Kim, S.C. 2018. Study on Species Identification for Pungnammun Gate (Treasure 308) in Jeonju, Korea. Journal of the Korean Wood Science and Technology 46(3): 278-284.

Park, J.J., Choi, M.J. 2017. The Periodic Process of the Wolseong palace and surroundings: Focused on the excavation results of moats of the wolseong palace, Archaeology. Journal of the Jungbu Archaeology Society 16(3): 5-38.

Park, S.J., Lee, W.Y., Lee, W.H. 1987. Timber organization and identification. Hyangmunsa, Seoul, Korea.

Park, W.K., Lee, K.H. 2007. Changes in the Species of Woods Used for Korean Ancient and Historic Architectures. Journal of Achitectural History 16(1): 9-28.

Pearson, C. 1988. Conservation of Marine Archaeological Objects. Butterworth-Heinemann, Oxford, UK. pp. 55-67.

Peña-Monné, J.L, Rubio-Fernández, V., González-Pérez, J.R., Rodanés, J.V., Picazo, J., Medina, J., Vázquez, M.P., Sampietro-Vattuone, M.M., Pérez-Lambán, F. 2014. Geoarchaeology of defensive moats: its importance for site localization, evolution and formation process reconstruction of archaeological sites in NE Spain. Journal of Archaeological Science 50: 383-393. Reimer, P., Austin, W., Bard, E., Bayliss, A., Blackwell, P., Bronk Ramsey, C., Butzin, M., Cheng, H., Edwards, R., Friedrich, M., Grootes, P., Guilderson,
T., Hajdas, I., Heaton, T., Hogg, A., Hughen, K., Kromer, B., Manning, S., Muscheler, R., Palmer, J., Pearson, C., van der Plicht, J., Reimer, R., Richards, D., Scott, E., Southon, J., Turney, C., Wacker, L., Adolphi, F., Büntgen, U., Capano, M., Fahrni, S., Fogtmann-Schulz, A., Friedrich, R., Köhler, P., Kudsk, S., Miyake, F., Olsen, J., Reinig, F., Sakamoto, M., Sookdeo, A., Talamo, S. 2020. The IntCal 20 Northern Hemisphere radiocarbon age calibration curve (0-55 cal kBP). Radiocarbon 62(4): 725-757.

Richter, H.G., Grosser, D., Heinz, I., Gasson, P.E. 2004. IAWA List of Microscopic Features for Softwood Identification. IAWA Journal 25(1): 1-70.

Rodgers, B.A. 2004. The archaeologist's manual for conservation. Springer Science + Business Media, New York, USA. pp. 33-67.

Seo, J.H., 2008, Conservation methodology for cultural heritage. Kyunginmunhwasa, Seoul, pp. 81-139.

Wheeler, E., Baas, P., Gasson, P.E. 1989. IAWA List of Microscopic Features for Hardwood Identification. IAWA bulletin n.s. 10(3): 219-332.

Yeongnam Institute of Cultural Properties. 2014. The ancient wetland site at Yimdang-dong, Gyeongsan (Wooden artifacts). Research Report of Antiquities Vol. 212. Daegu, Korea.

Yi, Y.H. 1997. Conservation of waterlogged wooden finds excavated in wet-site. Journal of Conservation Science 6(2): 126-140.

Zhuang, Y.J., Zhang, H., Fang, Y.M., Wang, H. 2017. Life cycle of a moat: a detailed micromorphological examination and broader geoarchaeological survey at the late Neolithic Wadian site, Central China. Journal of Archaeological Science: Reports 12: 699-711. 
A Fundamental Study of the Silla Shield through the Analysis of the Shape, Dating, and Species Identification of Wooden Shields Excavated from the Ruins of Wolseong Moat in Gyeongju

\title{
APPENDIX
}

\author{
(Korean Version)
}

\section{경주 월성 해자 유적 출토 목제방패의 형태, 연대 및 수종분석을 통한 신라 방패의 기초적 연구}

초록 : 경주 월성의 본격적인 발굴조사로 다양한 종류의 목제유물이 출토되고 있다. 특히 월성의 주위를 둘러싸고 있는 해자에서 다량 출토되었다. 본 연구에서는 월성 해자에서 출토된 목제방패 2점의 수종분석, 방사성탄소연대측정, 그리고 형태분 석을 통해 신라시대 방패에 대한 기초자료를 확보하고자 하였다. 연대측정 결과, 4 세기 중반에서 5 세기 초반에 벌채된 목재를 사용하여 제작되었음이 확인되었다. 수종분석 결과, 유물의 몸체는 소나무속 연송류로, 손잡이는 느티나무속 느티나무로 식별되 었다. 출토 목제방패의 제작 순서는 판목으로 가공된 판에 얇은 선으로 구획을 표시한 후 이중동심원을 구획하고 작은 구멍을 투공한 것으로 확인되었다. 구획선 사이의 간격을 측정한 결과 약 $6 \mathrm{~cm}$ 로 일정하고, 붉은 색과 검은 색으로 채색되어 있다. 형태 분석을 통해 유물의 너비는 각각 $50 \mathrm{~cm}, 36 \mathrm{~cm}$ 이상으로 추정했다.

\section{1. 서론}

월성 해자는 신라 왕성인 월성 외곽에 축조된 방어시설이다. 내부를 보호하기 위해 남천(南川)을 자연해자로 활용하고, 북·동. 서측은 성 외곽에 도랑을 판 후 물을 채워 방어시설로 사용하였다. 한반도에서 해자 등의 방어시설은 선사시대 취락의 환호를 시작으로 고대 도성의 성곽 등장과 함께 고구려 국내성, 백제 풍납토성, 신라 월성에서 축조되었던 것으로 확인되고 있다. 그 외, 중국과 일본 등에서도 고대 도성부터 중세에 이르기까지 인공 혹은 자연적인 해자를 다양한 형태로 조성한 사례가 다수 확인되고 있다(Park and Choi, 2017).

경주 월성의 본격적인 발굴조사로 월성 성벽과 해자(垓字)에서 다양한 종류의 목제유물이 출토되고 있다. 특히 월성의 주위를 둘러싸고 있는 해자에서 다량이 출토되고 있다. 이는 해자가 갖는 독특한 환경 때문이다. 물이 차 있던 해자는 일종의 저습지로 다른 곳보다 지면이 낮아 항상 물이 고여 축축한 상태가 유지되는 곳이다(Jung et al., 2010; Peña-Monné et al., 2014; Zhuang et al., 2017). 목재는 유기물질로 구성되었으며 시간이 흐를수록 곤충, 세균, 화학적 변화 등으로 조직이 분해되고 파괴되어 그 형태를 잃고 결국에는 없어진다. 그러나 저습지에서는 흔히 뻘층 또는 진훍층에 의해 밀폐된 환경이 형성되어 유기물질의 분해 활동을 제한하는 저산소 또는 무산소 환경이 만들어진다. 이는 일반적인 환경보다 분해 속도가 더뎌지며, 목재의 주성분이 분해된 공간에 물이 채워져 목제유물이 폐기 당시의 모습에 가깝게 남아있게 된다(Pearson, 1988; Yi, 1997; Rodgers, 2004; Seo, 2008).

이렇게 원형에 가깝게 출토된 목제유물은 고고학과 자연과학적인 연구를 통해 당시의 자연 환경 복원은 물론 당시 사람들이 사용한 생활용구, 도구, 건축부재 등을 통해 생활상을 복원하는 중요한 정보를 제공한다. 현재 우리나라에서는 많은 유적에서 출토되는 목제유물과 고건축물의 부재에 대한 수종분석, 연대측정, 제작기법, 옻칠분석 등 다양한 연구가 진행되고 있다(Lee and Kim, 2015; Nam et al., 2015; 2017; 2018; Hwang et al., 2018; Park et al., 2018; Lee and Kim, 2018; Eom and Park, 2018; Lee et al., 2018; 2021, Lee and Han, 2018; Cho et al., 2019; Hwang et al., 2020).

월성 해자에서는 생활도구(빗, 국자, 용기, 칠기 등)와 건축부재(판재, 결구부재 등), 용도가 명확하지 않은 목제품 등 목재로 제작된 유물이 785점 출토되었다. 그 중 가장 흥미로운 유물은 목제방패 2점이다(Fig. 1). 본 연구에서는 목제방패 2점의 수종분 석, 방사성탄소 연대측정과 같은 자연과학적 분석, 그리고 형태분석을 통해 신라시대 방패에 대한 기초자료를 확보하고자 하였다.

\section{2. 재료 및 방법}

\section{1. 연구지역}

경주 월성은 경주시 인왕동 $387-1$ 번지 일원에 위치하며 $\left(35^{\circ} 49^{\prime} 51^{\prime \prime} \mathrm{N}, 129^{\circ} 13^{\prime} 34^{\prime \prime} \mathrm{E}\right)$, 총 면적은 약 $193,845 \mathrm{~m}^{2}$ 정도이다. 동서와 남북 길이는 각각 $890 \mathrm{~m}, 260 \mathrm{~m}$ 이고, 바깥 둘레는 $2,340 \mathrm{~m}$ 인 긴 반달 모양을 하고 있다. 서쪽으로 형산강, 북쪽으로 
북천, 남쪽으로는 남천이 흐르며 독립구릉을 이루고 있다. 월성 정상부는 넓게 평탄면을 이루고 가장자리에는 평탄면보다 $2 \sim \mathrm{m}$ 높은 성벽이 남아있다. 월성 구릉지는 외부로부터 접근하는 통로가 전체적으로 조망되는 입지적 장점을 가진다. 이곳에서 는 경주 분지를 둘러싸고 있는 모든 산지의 정상부를 볼 수 있었을 것으로 추정된다 (Gyeongju National Research Institute of Cultural Heritage (GNRICH), 2010).

\section{2. 재료}

경주 월성 해자지구 발굴조사 중 1호 해자에서 2016년과 2018년에 2점의 목제방패가 출토되었다. 최하부층의 안정적 층위에 서 출토되었으며 손잡이 달린 것과 없는 것 2가지 형태였다. 출토된 목제방패는 이중동심원과 띠 모양을 날카로운 도구를 이용하여 밑그림을 그린 흔적과 붉은 색과 검은 색으로 채색, 일정 간격의 작은 구멍이 확인되었다. 본 연구에서는 출토된 목제방패의 원형 복원을 위한 실측을 통한 형태분석, 수종분석, 연대분석의 대상으로 하였다.

\section{3. 방법}

2.3.1. 수종분석

유물의 형태를 유지할 수 있게 외관상 보이지 않는 부위에서 최소한의 절편을 면도칼(Dorco Co., Ltd.)을 사용하여 채취하였 다. 채취된 3 단면(횡단면, 방사단면, 접선단면)의 박편은 임시봉입제 $(50 \%$ 글리세린수용액)로 봉입한 임시프레파라트를 제작하 여 분석하였다. 제작된 프레파라트는 광학현미경(Nikon ECLIPSE E200)으로 구성세포를 관찰하고, 그 특징을 사진 촬영하였다. 수종분석은 목재조직과 식별(Park et al., 1987), 한국산 목재의 성질과 용도(Lee, 1997), 한국산목재의 조직구조(Lee, 1994), 목재해부학(Kwon et al., 2020), IAWA List of Microscopic Features for Softwood Identification (Richter et al., 2004), IAWA List of Microscopic Features for Hardwood Identification (Wheeler et al., 1989)을 참조하여 식별하였다.

\subsection{2. 연대분석}

유물의 형태에 영향을 주지 않게 보이지 않는 부위에서 약 $100 \mathrm{mg}$ 정도의 극미량의 시료를 채취하였다. 채취된 시료를 복수기관(일본 Paleo Labo社, 미국 BETA社)에 측정을 의뢰하였다. 시료를 목분으로 제작하여 $\mathrm{AAA}($ 산-알카리-산)처리 후 가속기질량분석기로 측정하였다. 측정된 ${ }^{14} \mathrm{C}$ 연대는 가장 최근의 보정곡선인 $\mathrm{IntCal} 20$ (Reimer et al., 2020)을 적용하여 Oxcal 프로그램으로 보정연대를 산출하였다(Bronk, 1995).

\section{3. 결과 및 고찰}

\section{1. 형태분석}

경주 월성 해자에서는 2점의 목제방패가 출토되었다. 손잡이가 달린 것과 달리지 않은 것이 출토되었다. 두 유물의 형태적 주요 특징은 몸체는 판목판(flat grain board, 板目板)이며, 두께 1.0 1.2cm로 둥글게 가공되었다. 유물은 날카로운 도구를 이용하 여 판재의 표면에 얇은 선으로 구획하고 이중동심원을 표시한 후 채색하는 순서로 방패가 제작되었다. 또한, 일정 간격으로 작은 구멍이 투공되어 있는데, 실과 같은 재료로 엮어서 강도를 강화하기 위한 것으로 보인다. 그리고 그동안 밝혀지지 않았던 손잡이의 존재와 부착방법을 확인할 수 있었다.

\subsection{1. 손잡이 달린 목제방패(Fig. 1-1)}

유물의 잔존 길이는 $73 \mathrm{~cm}$, 너비 $14.4 \mathrm{~cm}$ 이며 나이테 3 개가 포함된 두께 약 $1.0 \mathrm{~cm}$ 이다. 유물의 일부만 10 개의 편으로 분리된 상태로 수습되었다. 3 개의 이중동심원(二重同心圓)과 띠 모양의 수평구획선 7 개가 확인되었고, 붉은 색과 검은 색으로 채색되어 있다. 2 개의 이중동심원은 인접해 있으며, 나머지 1 개는 떨어져 있다. 유물의 뒷면에는 내경 약 $9.6 \mathrm{~cm}$ 의 손잡이가 위아래에 나무못 3 개로 고정되어 있다.

선이 명확한 수평구획선 7개 사이의 6구간을 3지점씩 총 18지점을 측정한 결과는 최소 $5.8 \mathrm{~cm}$, 최대 $6.5 \mathrm{~cm}$, 평균 $6.1 \mathrm{~cm}$ 로 확인되었다. 동심원 사이 5 지점을 측정한 결과는 최소 $6.0 \mathrm{~cm}$, 최대 $6.3 \mathrm{~cm}$, 평균 $6.1 \mathrm{~cm}$ 로 확인되었다. 이 유물의 구획은 약 $6 \mathrm{~cm}$ 를 전후한 간격으로 구획되었다. 따라서 이중동심원의 직경은 $24 \mathrm{~cm}$ 로 계산되었고 이중동심원 사이의 간격이 $2 \mathrm{~cm}$ 로 측정되어, 이 유물의 너비는 최소 $50 \mathrm{~cm}$ 이상으로 추정했다. 
A Fundamental Study of the Silla Shield through the Analysis of the Shape, Dating, and Species Identification of Wooden Shields Excavated from the Ruins of Wolseong Moat in Gyeongju

3.1.2. 손잡이 없는 목제방패(Fig. 1-2)

유물의 잔존 길이는 $95.9 \mathrm{~cm}$, 너비 $26.3 \mathrm{~cm}$ 이며 나이테 6 개가 포함된 두께 $1.2 \mathrm{~cm}$ 이다. 유물의 일부만 9 개의 편으로 분리된 상태로 수습되었다. 이중동심원 1 개와 띠 모양의 수평구획선 16 개가 확인되었고, 검은 색으로만 채색되어 있다. 손잡이가 부착되어 있었던 흔적은 확인되지 않았다.

선이 명확한 수평구획선 16 개 사이의 15 구간을 3 지점씩 총 45 지점을 측정한 결과는 최소 5.0 , 최대 $6.4 \mathrm{~cm}$, 평균 $5.7 \mathrm{~cm}$ 로 확인되었다. 동심원 사이 5 지점을 측정한 결과는 최소 $5.3 \mathrm{~cm}$, 최대 $6.3 \mathrm{~cm}$, 평균 $5.9 \mathrm{~cm}$ 로 확인되었다. 이 유물의 구획은 약 $6 \mathrm{~cm}$ 를 전후한 간격으로 구획되었다. 따라서 이중동심원의 직경은 $24 \mathrm{~cm}$ 로 계산되었고 이중동심원과 온전히 잔존하는 측면과의 간격이 $6 \mathrm{~cm}$ 로 측정되어, 이 유물의 너비는 최소 $36 \mathrm{~cm}$ 이상으로 추정했다.

\subsection{3 출토 사례}

우리나라에서 출토되는 유물 중 방패로 추정 또는 확인된 예는 3세기 후반으로 비정(比定)되는 노포동 31호분 칠(漆) 흔적이 최초이다(Lee, 2015). 복천동과 대성동 고분군 등 삼국시대 고분에서 확인되었다. 저습지 유적에서 방패로 추정되는 유물은 경산 임당동 저습지유적에서 3점이 출토된 사례가 있다. 임당동 출토 방패 유물은 날카로운 도구로 이중동심원과 띠 모양의 밑그림을 그리고 붉은 색과 검은 색으로 채색하였다. 일정 간격으로 작은 구멍이 있다. 대부분 소실되고 일부만 출토되어 전체적인 모습을 이해하는데 어려움이 있다(Fig. 2).

벽화에 쓰인 묵서를 근거로 축조(築造) 시기가 357년(고구려 고국원왕 27년)으로 추정되는 안악3호분 행렬도(NRICH와 Seoul Baekje Museum (SBM), 2018)에서는 2가지 유형의 방패와 2가지 휴대방법이 확인된다. 벽화를 통해 확인된 방패 유형은 붉은색의 타원형 2 개를 붙인 형태와 길쭉한 마름모 형태이다. 방패 내부의 구조는 휴대하는 방법에 의해 방패 내부 손잡이의 가능성을 유추해 볼 수 있다. 벽화에서 확인된 휴대방법은 옆구리에 끼고 이동하는 방법(Fig. 3 확대사진 왼쪽 상단)과 긴 방향으로 측면에서 들고 가는 방법이다(Fig. 3 중앙 및 확대사진). 이러한 이동 모습을 살펴보면 방패의 내부에 손잡이가 있어야 가능한 형태이고, 이를 통해 방패에 손잡이 부착 가능성을 추정해 볼 수 있다.

임당동 저습지의 사례는 방패의 몸체에 해당하는 일부분이 출토되었으나 손잡이 등의 부속구의 부착 흔적이 확인되지는 않았다. 그리고 유물의 잔존 상태로는 방패의 전체적인 형태를 추정하기 힘든 점에서 고구려벽화 고분을 통해서 손잡이를 부착한 방패와 부착하지 않은 방패 2종류가 삼국시대에 이용하고 있었음을 확인할 수 있다.

\section{2. 수종분석 결과}

3.2.1. 소나무과 소나무속 연송류 (Pinaceae Pinus soft pine group)

출토 목제방패의 몸체는 침엽수재로 조재와 만재의 이행은 비교적 완만하였으며, 박벽의 에피데리얼 세포를 가진 수직세포간 구(Axial intercellular canal)를 횡단면에서 관찰할 수 있었다(Fig. 4 A). 방사단면에서 방사조직은 방사가도관과 방사유세포로 이루어져 있었고, 교분야벽공은 창상형(Window-like)이었다. 가도관벽의 유연벽공은 1 열로 존재하였다(Fig. 4 B). 접선단면의 방사조직은 단열방사조직과 수평세포간구(Radial intercellular canal)를 갖는 방추형방사조직(Fusiform ray)으로 구성되어 있다 (Fig. 4 C). 소나무속 중에서도 방사가도관이 평활하여 거치상비후(Dentate thickening)가 확인되는 경송류(Hard pine group)와 는 구별됨으로 이 수종은 연송류로 식별할 수 있었다.

\subsection{2. 느릅나무과 느티나무속 느티나무 (Ulmaceae Zelkova serrata (Thunb.) Makino.)}

출토 목제방패의 손잡이는 횡단면상에서 공권은 대도관이 1 2열인 환공재(Ring-porous wood)이다. 공권부의 대도관은 대개 원형으로 독립적이며 공권 외 소도관은 다각형으로 짧은 접선상의 집단관공을 이룬다(Fig. 4 D). 방사단면에서는 단천공판 (Simple perforation plate)이 확인되고, 도관 주위에서는 축방향유세포의 유세포 스트랜드(Parenchyma strand)가 관찰된다. 이성형방사조직(Heterogeneous ray)으로 평복세포(Procumbent ray cell)와 방형세포(Square ray cell)로 이루어져 있으며, 방형 세포에는 능형결정(Rhomboidal crystal)이 흔히 관찰된다(Fig. 4 E). 접선단면에서는 소도관에 나선비후(Helical thickening)가 관찰된다. 방사조직은 대부분 5 6열이 현저하지만 1 3열도 혼재한다. 방사조직은 양 끝단이 다른 방사조직보다 긴 이성피형이 다(Fig. 4 F). 우리나라의 느티나무속에는 느티나무 1종만 생장하고 있어, 느티나무로 식별하였다.

3.2.3. 출토 목제방패의 수종분석 결과 고찰

출토 목제방패의 몸체 제작에 이용된 소나무속 연송류(잣나무)로, 『신라민정문서(新羅民政文書)』에 잣나무에 대한 내용이 
실려 있다. 내용 중에 뽕나무(桑), 호두나무(楸子木), 잣나무(柏子木)를 이전부터 자라고 있었던 그루수와 새로 심은 그루수를 따로 기록하여 두었다. 이것은 최초의 인공조림 기록으로 잣나무는 나라에서 관리하는 나무 중의 하나였다. 나무가 연하고 수지(樹脂)가 적어 색도 연하므로 연송류(軟松類; soft pine, white pine)로 불리며, 잣나무가 이에 속한다. 경송류(硬松類; hard pine, pitch pine)인 소나무에 비해 잣나무는 재질이 연하여 제작에 용이했을 것으로 보인다. 손잡이 제작에 이용된 느티나무는 추출물이 많아 썩거나 곤충의 피해를 입는 경우가 적고, 건조를 할 때 갈라지거나 비틀림이 적으며, 마찰이나 충격에 강하며 단단하기까지 하다(Park and Lee, 2007).

삼국시대 경주 월성 유적과 안압지 유적 (Lee, 2007; Nam, 2018), 황룡사 광장 유적 (Foundation of Silla Cultural Heritage Research Institute, 2018), 경산 임당동 저습지유적 (YICP, 2014) 등에서 출토된 목제유물과 우리나라 건축물에 사용된 목재의 제작에 잣나무와 느티나무가 이용되었다(Park and Lee, 2007).

\section{3. 연대측정 결과}

경주 월성 출토 목제방패 2점의 방사성탄소연대 측정 결과를 다음 Table 3과 Fig. 5에 나타내었다. 손잡이 달린 목제방패는 보다 신뢰성 있는 결과를 위해 서로 다른 기관에 측정을 의뢰하여 교차검증을 실시하였다.

손잡이 달린 목제방패의 경우, 두 기관(BETA社, Paleo Labo社)의 측정치로 계산된 보정연대( $95.4 \%$ 신뢰구간)는 각각 $\mathrm{AD}$ 382 541년과 AD 262 274년 또는 AD 348 428년으로 산출되었다. 두 기관의 산출된 연대구간이 서로 포함하고 있어 신뢰성이 확인되었다. 이 결과를 적극적으로 해석하면, $\mathrm{AD} 382$ 428년 사이에 벌채된 목재를 사용하여 제작된 것으로 볼 수 있다. 손잡이 가 없는 목제방패의 경우, 보정연대가 $95.4 \%$ 신뢰구간에서 $\mathrm{AD}$ 264 273년 또는 $\mathrm{AD} 348$ 420년으로 산출되었다.

2 개의 방패 추정 목제품의 교정연대는 4 세기 중반에서 5 세기 초반에 연대들이 중첩되고 있다. 또한 유적의 동일한 층위에서 출토하는 점에서 같은 시기에 제작 - 사용 후 폐기된 것으로 판단된다. 또한, 이 시기는 월성 해자의 호안 목제구조물의 연대측정 결과 및 해자 최하층 동식물 유체의 측정결과(Ahn, 2018)인 4세기 후반 5세기 초와 일치하는 연대이다. 따라서 이 유물과 호안 목제구조물은 같은 시기에 존재하였음을 알 수 있다.

\section{4. 결론}

본 연구에서는 경주 월성 해자지구 발굴조사 중 출토된 목제방패 2점을 형태, 수종, 연대분석을 실시하였고, 다음과 같은 결론을 얻을 수 있었다.

출토 목제방패의 제작 순서는 판목으로 가공된 판에 얇은 선으로 구획을 표시한 후 이중동심원을 구획하고 작은 구멍을 투공한 것으로 확인되었다. 구획선 사이의 간격을 측정한 결과 약 $6 \mathrm{~cm}$ 전후로 일정하고, 붉은 색과 검은 색으로 채색되어 있다. 각 유물의 추정 너비는 최소 $50 \mathrm{~cm}, 36 \mathrm{~cm}$ 로 계산되었다.

수종분석 결과, 유물의 몸체는 재질이 연하여 제작에 용이한 소나무과 소나무속 연송류로, 손잡이는 비틀림이 적고 단단한 느릅나무과 느티나무속 느티나무로 식별되었다.

방사성탄소연대측정 결과, 출토된 목제방패는 4 세기 중엽에서 5 세기 초에 벌채된 목재를 사용하여 제작되었음이 확인되었다. 출토된 유물을 통해 방패의 형태를 확인할 수 있는 것은 임당동 유적과 월성 유적 2곳에서 출토된 삼국시대 목제방패뿐이다. 경주 월성유적의 목제방패는 이중동심원 내에 붉은 색과 검은 색을 이용해 채색하고 있다. 이와 같은 구도배치와 채색은 임당동 유적 출토 목제방패에서도 확인된다. 구도배치와 채색의 목적이 장식 혹은 의례를 위한 것인지는 추가 사례조사와 함께 연구가 필요하다.

경주 월성유적에서 칠(漆)의 흔적, 일부 조각만으로 출토되어 추정되었던 삼국시대 방패가 완전하게 복원 가능한 형태로 출토되었다. 특히 휴대방법에 의해 추정된 2 가지 형태가 모두 확인된 점은 벽화와 일치하고 있다. 경주 월성유적의 방패는 신라시대 무장체계 및 얇은 판재 가공과 같은 고도의 목재 가공 기술을 보여주는 유물로 평가된다.

현재 출토된 목제유물의 수종 - 연대분석과 형태에 대한 일부 분석이 이루어졌지만, 향후 출토된 유물의 도구흔적, 가공방법 등의 형태적인 분석과 사용된 안료분석을 통하여 신라시대 방패의 복원을 위한 자료를 확보할 수 있을 것이다. 